\title{
A quick and effective estimation of algal density by turbidimetry developed with Chlorella vulgaris cultures
}

\author{
Noelia S. Ferrando ${ }^{1}$, Hernán H. Benítez ${ }^{1}$, Néstor A. Gabellone ${ }^{1, *}$, María C. Claps ${ }^{1}$ and Pablo \\ R. Altamirano ${ }^{2}$ \\ ${ }^{1}$ Instituto de Limnología R.A. Ringuelet (CCT-La Plata CONICET, Facultad de Ciencias Naturales y Museo, \\ UNLP), Boulevard 120 y 62, 1900 La Plata, Argentina. \\ ${ }^{2}$ Cátedra de Cálculo Estadístico y Biometría, Facultad de Ciencias Agrarias y Forestales, Universidad Nacional \\ de La Plata, 60 y 119, 1900 La Plata, Argentina.
}

* Corresponding author: gabellon@ilpla.edu.ar

Received: 28/05/2014

Accepted: 10/06/2015

\begin{abstract}
A quick and effective estimation of algal density by turbidimetry developed with Chlorella vulgaris cultures

The use of Chlorella vulgaris Beijerinck as a food source for zooplankton requires the optimization of algal-culture conditions for prolonged growth maintenance. In this study, we developed a method that relates algal density to culture turbidity to estimate culture biomass. This method was improved by applying digital analysis for algal counting, which promotes accuracy, low culture disturbance, easy repetition and the rapid acquisition of results. Two 3-L cultures of $C$. vulgaris, maintained for two weeks with continuous lighting (eight light-emitting diodes at $50 \mu \mathrm{mol}$ photons $\mathrm{m}^{-2} \cdot \mathrm{s}^{-1}$, at $660 \mathrm{~nm}$ ) and aerators to prevent algal sedimentation, reached turbidities of 214 and 280 NTUs, respectively. Sample counting was performed using digital images obtained with an inverted microscope. Aliquot sedimentation was compared with or without previous homogenization through photographs taken in the central, middle, and peripheral sectors of the Utermöhl settling chambers. For each procedure, we counted between 17 and 404 individuals image ${ }^{-1}$, requiring, on average, one minute image ${ }^{-1}$. At low turbidity ( $<40 \mathrm{NTU}$ ), the data dispersion was similar between the two protocols (error range, 16 to $60 \%$ ); at higher turbidity, the direct sedimentation alone gave a larger error $(31-50 \%)$ than with prior homogenization (5-13\%). Regression analysis at low data fit $(67 \%)$ suggested that the sedimentation heterogeneity of non-homogenized samples corresponded to a pattern of settled algae having increasing density from the periphery to the centre of the chamber, but with homogenization, a better model fitting (99\%) resulted, contributing to greater consistency with that procedure. We consider that this turbidometric protocol could be used successfully with cultures of algae that have geometrical shapes recognizable by the image software.
\end{abstract}

Key words: Chlorella vulgaris, culture, turbidimetry, cell counting digital analysis, homogenization.

\section{RESUMEN}

Una estimación rápida y eficaz de la densidad algal por medio de un método turbidimétrico desarrollado con cultivos de Chlorella vulgaris

El uso de Chlorella vulgaris Beijerinck como alimento para el zooplancton implica la necesidad de optimizar el cultivo de algas para mantener su crecimiento en el tiempo. En este trabajo se desarrolló un método que relaciona la densidad del cultivo con la turbidez para estimar la biomasa algal. Esta técnica se ha mejorado mediante la aplicación del análisis digital para el recuento de las algas que promueve la exactitud y reduce el disturbio en el cultivo, con obtención rápida y fácil de resultados repetibles. Se realizaron dos cultivos de C. vulgaris en recipientes de 3 L con aireación e iluminación continua (50 umol fotones $\mathrm{m}^{-2} \cdot \mathrm{s}^{-1}$ a $660 \mathrm{~nm}$ ), alcanzando 214 y $280 \mathrm{NTU}$, respectivamente. El recuento de las muestras se realizó por medio de imágenes digitales tomadas con un microscopio invertido. Se aplicaron dos técnicas para el recuento de las alícuotas: la sedimentación directa y la sedimentación con homogeneización previa. Con el fin de comparar el ajuste de ambos métodos de sedimentación, las fotografías fueron tomadas en los sectores central, medio y periférico de la cámara de sedimentación. Para ambas técnicas se contaron un mínimo de 17 individuos imagen ${ }^{-1}$ y un máximo de 404 individuos imagen $^{-1}$, con un tiempo promedio de un minuto por imagen. A niveles bajos de turbidez $(<40 N T U)$ la dispersión de los datos fue similar entre ambas técnicas (rango error: 16-60\%). Para niveles superiores de turbidez, en la técnica de sedimentación directa se observó un 
mayor rango de error (31-50\%) mientras que en la técnica con homogenización previa osciló entre 5 y $13 \%$. El análisis de regresión evidenció un bajo ajuste de los datos (67\%), que en la sedimentación sin homogeneización responde a un patrón reiterado de aumento de densidad algal desde la periferia hacia el centro de la cámara de sedimentación. La inclusión de una homogeneización previa promueve un mejor ajuste del modelo (99\%) y determina un incremento en la consistencia del método. Con los resultados obtenidos se demuestra que la técnica turbidimétrica desarrollada puede ser utilizada con éxito en cultivos de especies de algas cuyas formas geométricas sean reconocidas por el procesador de imágenes.

Palabras clave: Chlorella vulgaris, cultivo, turbidimetría, recuento digital de células, homogeneización.

\section{INTRODUCTION}

The chlorophyte Chlorella is characterized by the ability to grow rapidly in culture and a capacity to utilize organic and inorganic substances as nutritional substrates (Xu et al., 2006; Chinnasamy et al., 2010). For these reasons, species of Chlorella have been investigated for their inclusion in biotechnological processes. Some of these algae are used as remediation agents (Travieso et al., 2006; Altenburger et al., 2008) and also for atmospheric carbon-dioxide reduction (Converti et al., 2009; Brennan \& Owende, 2010). Moreover, species of Chlorella are used in the production of oxygen; the production of specific chemical agents such as pigments, carbohydrates, lipids, and drugs (Chisti, 2007); and as food for molluscs, crustaceans, and fish (De Pauw et al., 1984; Shah et al., 2003).

Species of Chlorella, among various types of algae, are routinely being produced as a food source to maintain the stable mass production of zooplanktonic rotifers and crustaceans (FloresBurgos et al., 2003). This chlorophyte is appropriate for rotifer cultures, but because of its size, the alga could be inefficient for cultures of cladocerans (Peña-Aguado et al., 2005).

Furthermore, a variety of methods has been proposed for monitoring the status of algal cultures: namely, automated counts with electronic meters (Javanmardian \& Paisson, 1992), chlorophyll analyses (Travieso et al., 2006), spectrophotometric determinations at $650 \mathrm{~nm}$ (Wang et al., 2007), turbidity measurements by a photosensitive transistor included in a turbidostat (Skipnes et al., 1980), and enumeration by microscope in Neubauer chambers (Aguirre Ramírez et al., 2007; Ortiz Moreno et al., 2012; Rodas Gaitán et al., 2012). Nevertheless, with these methods, there remains a critical lack of a fast and reliable method for determining algal density that would allow an adjustment of the parameters in real time. The traditional techniques of direct counting (Lund et al., 1958) and spectrophotometric chlorophyll estimation (APHA, 1995) are not capable of accomplishing this, because they do not involve procedures that allow the quick acquisition of data. In contrast, turbidity measurements can be performed instantly. Turbidity is a measure of light scattering and absorption caused by the presence of suspended particles in a fluid. The nature of the particles can be inorganic (e.g., silt and clay) or organic (e.g., bacterioplankton, phytoplankton, and zooplankton) (Wetzel \& Likens, 1991). The turbidity is a function of particle concentration, but also of particle size and shape. In a pure monospecific algal culture, where all the suspended particles are presumably similar, turbidity can be used for estimating algal density. Although the estimation of Chlorella vulgaris growth by turbidimetry has already been reported (Aguirre Ramírez et $a l ., 2007)$, the relationship between these two parameters -i.e., turbidity and algal density- in the form of a mathematical model has scarcely been discussed.

On the basis of these considerations, the objectives of this study were (1) to evaluate turbidimetry as a simple and immediate method for estimating algal culture density, (2) to determine a fast and reliable technique for counting individual algae to routinely monitor the validity of the estimation by turbidimetry, (3) to identify the methodological errors affecting the relationship 
between the two methods of density assessment, (4) to propose specific modifications of the procedure to reduce those errors, and (5) to define the scope and limitations of the technique as proposed.

\section{METHODS}

\section{Algal cultures}

Two parallel cultures of $C$. vulgaris Beijerinck were started in 3-L flasks containing tap water $(1000 \mu \mathrm{S} / \mathrm{cm})$ plus nutrients $(600 \mu \mathrm{g} \mathrm{P} / \mathrm{L}$ as $\mathrm{K}_{2} \mathrm{HPO}_{4}$ and $6000 \mu \mathrm{g} \mathrm{N} / \mathrm{L}$ as $\mathrm{KNO}_{3}$ ). Each flask was isolated from the ambient natural light by aluminium foil and an alternative high-efficiency light source (light-emitting diodes: LEDs) was applied, which permitted the retrieval of algal cultures with densities at orders of magnitude greater than with conventional lighting (Skipnes et al., 1980; Wang et al., 2007). A plate with 8 LEDs, emitting $50 \mu \mathrm{mol}$ photon $\mathrm{m}^{-2} \mathrm{~s}^{-1}$, was placed at the mouth of the flask, and the irradiance provided by the plate was measured with a LI-250A Light Meter (Li-Cor, Lincoln, Nebraska, USA) containing a spherical sensor. The lighting was continuous (i.e., photoperiod, 24:0, L:D), and aerators were installed to prevent algal sedimentation. The algal density in each culture was estimated by means of a 2100P Laboratory Turbidimeter (Hach, Loveland, Colorado, USA) and measured in nephelometric units (NTUs). Incubations were run for two weeks, at which time Culture 1 had reached a turbidity of 214 NTU and Culture 2, a turbidity of 280 NTU. A diluted sample of each culture was filtered through Whatman GF/F glass microfiber filters, and the concentration of chlorophyll ' $a$ ' was measured by spectrophotometry (Method $10200 \mathrm{H}$, APHA, 1995) and calculated according to Lorenzen (1967). The concentration of chlorophyll ' $a$ ' was greater than $300 \mathrm{mg} / \mathrm{m}^{3}$ in both cultures, whereas the absence of autospores and dead cells indicated the healthy condition of the algae.
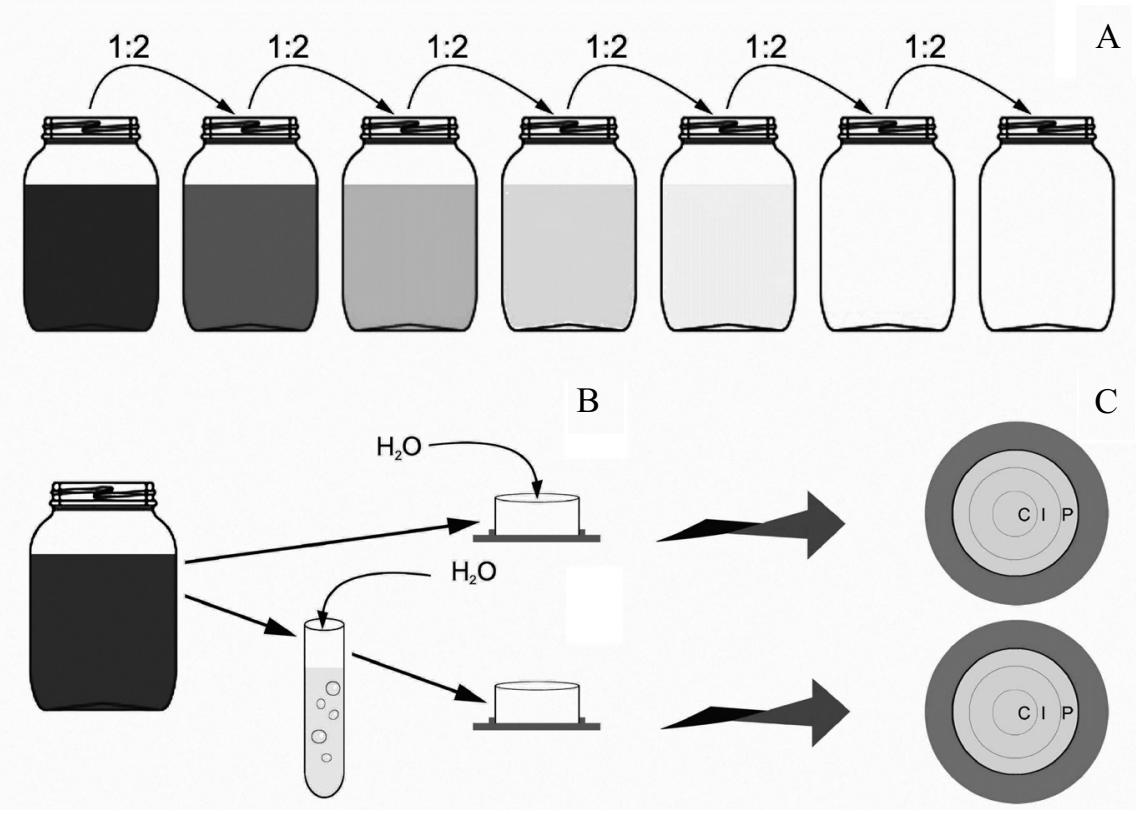

Figure 1. Sequence of the experimental steps. A: serial-dilution scheme of algal cultures. B: flow diagram showing the algalsettling step with and without prior homogenization. C: diagram of the three sectors of the settling-chamber floor (designated as central, middle, and peripheral) from which digital images were taken with an inverted microscope. Secuencia de los experimentos. A: Dilución de los cultivos algales. B: Diagrama de flujo que muestra los pasos de la sedimentación algal, con y sin homogeneización previa. C: Diagrama de los tres sectores del fondo de la cámara de sedimentación (denominados central, medio y periférico) para la toma de las imágenes digitales con microscopio invertido. 
Table 1. Dilutions performed and aliquots settled in the cultures of Chlorella vulgaris. Diluciones realizadas y alícuotas sedimentadas de los cultivos de Chlorella vulgaris.

\begin{tabular}{ccccc}
\hline $\begin{array}{c}\text { Culture dilution } \\
\text { factor }\end{array}$ & $\begin{array}{c}\text { Culture 1 } \\
\text { turbidity (NTU) }\end{array}$ & $\begin{array}{c}\text { Culture 2 } \\
\text { turbidity (NTU) }\end{array}$ & $\begin{array}{c}\text { Uthermöhl } \\
\text { dilution factor }\end{array}$ & $\begin{array}{c}\text { Settled } \\
\text { aliquot (ml) }\end{array}$ \\
\hline $1: 1$ & 214 & 280 & $2: 100$ & 0.1 \\
$1: 2$ & 86.1 & 108 & $4: 100$ & 0.2 \\
$1: 4$ & 34.7 & 41.8 & $8: 100$ & 0.4 \\
$1: 8$ & 15.5 & 18.3 & $12: 100$ & 0.6 \\
$1: 16$ & 6.78 & 8.61 & $16: 100$ & 0.8 \\
$1: 32$ & 3.77 & 4.07 & $20: 100$ & 1.0 \\
$1: 64$ & 2.03 & 2.36 & $24: 100$ & 1.2 \\
\hline
\end{tabular}

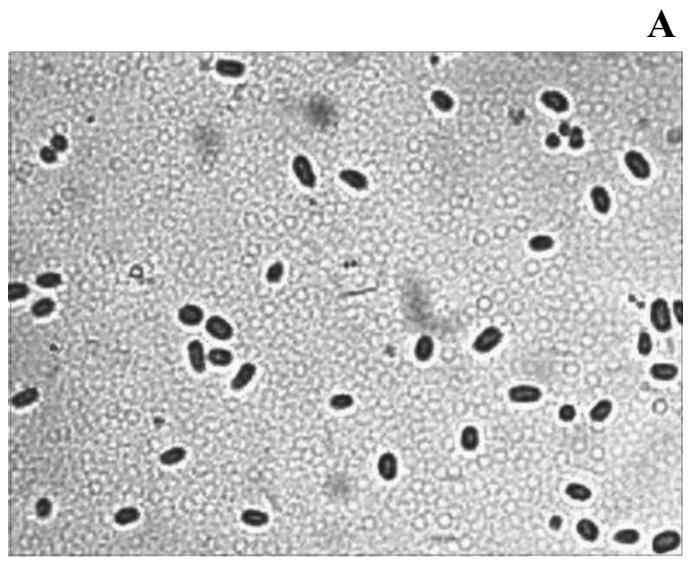

B

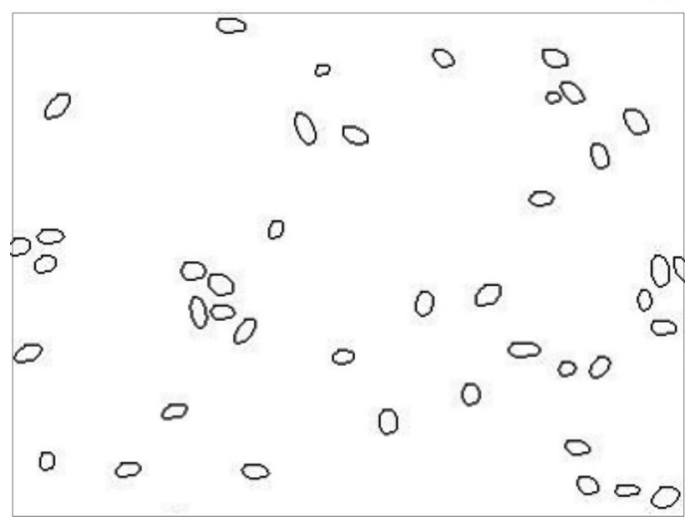

Figure 2. Representative images of individuals of Chlorella vulgaris. A: original microscopic image. B: image processed by the Image $\mathbf{J}$ software. Imágenes representativas de individuos de Chlorella vulgaris. A: imagen original de microscopio. B: imagen procesada mediante el software Image J.

\section{Sample preparation}

From the two exponentially growing cultures of C. vulgaris, we performed six successive 1:2 dilutions of the algal suspensions with tap water to obtain exponentially decreasing turbidities at seven different levels (Fig. 1A; Table 1). From each dilution, two 5-ml samples were removed and fixed with acetic lugol solution ( $1 \% \mathrm{v} / \mathrm{v})$ to facilitate the algal sedimentation in the settling chambers (APHA, 1995).

\section{Sedimentation method}

In all instances, settling chambers of $5 \mathrm{ml}$ were used. Because of the high algal concentration, a specific dilution for each sample had to be performed to maintain the density of the sample within the optimum range for counting in the chamber (Table 1). Aliquots were settled in two ways. First, in the direct settling protocol (DS), an aliquot of the sample from the algal suspension was placed in each chamber, and tap water was added to fill the total volume of the chamber. Therefore, the dilution here was carried out through the simple mixing involved in the filling of the settling chamber (Fig. 1B). Alternatively, in algal settling with previous homogenization (HS), the dilution of each aliquot from the algal suspension was performed as a separate prior step in a test tube. The original aliquot was first diluted in triplicate to a final volume three times greater than that of the settling chamber, and the resulting suspension was then homogenized by bubbling for 5 seconds before immediate transfer of $5 \mathrm{ml}$ to the chamber.

Because of the height of the settling chamber $(2 \mathrm{~cm})$ and the small size of $C$. vulgaris, all samples were left for $24 \mathrm{~h}$ to insure the complete sedimentation of the algae according to the criteria regarding settling times reported previously (Utermöhl, 1958; Willén, 1976; HELCOM, 2014). 
Table 2. Results of the Chlorella vulgaris counts by image analysis: turbidity values, algal densities, and mean percent errors for protocols with and without homogenization. Resultado del conteo por imágenes realizado para Chlorella vulgaris: valores de turbidez, densidad algal y error porcentual promedio para los métodos con y sin homogeneización previa.

\begin{tabular}{|c|c|c|c|c|c|}
\hline \multicolumn{3}{|c|}{$\begin{array}{l}\text { Non-homogenized sedimentation } \\
\text { method }\end{array}$} & \multicolumn{3}{|c|}{$\begin{array}{l}\text { homogenized sedimentation } \\
\text { method }\end{array}$} \\
\hline Turbidity (NTU) & Mean (individual/image) & Error $(\%)$ & Turbidity (NTU) & Mean (individual/ image) & Error $(\%)$ \\
\hline 214.0 & 136 & 49.7 & 280.0 & 357 & 12.7 \\
\hline 86.1 & 153 & 46.2 & 108.0 & 164 & 4.5 \\
\hline 34.7 & 215 & 31.9 & 41.8 & 143 & 4.7 \\
\hline 15.5 & 157 & 35.2 & 18.3 & 213 & 26.3 \\
\hline 6.8 & 140 & 16.4 & 8.6 & 101 & 22.5 \\
\hline 3.9 & 148 & 29.2 & 4.1 & 66 & 19.5 \\
\hline 2.0 & 102 & 46.5 & 2.4 & 125 & 59.3 \\
\hline
\end{tabular}

\section{Counting methods}

Counts of the samples were performed by means of digital images obtained through an inverted microscope (40×). To compare the fit of both sedimentation methods, photographs were taken according to a predetermined scheme of monitoring the settling chamber floor, which involved a separate estimation of the central, middle, and peripheral sectors (Fig. 1C). All images were processed with the software Image J version 1.46 (Ferreira $\&$ Rasband, 2012). The results were then transformed into algal densities (individuals $/ \mathrm{ml}$ ) for subsequent statistical analysis.

$\mathbf{A}$
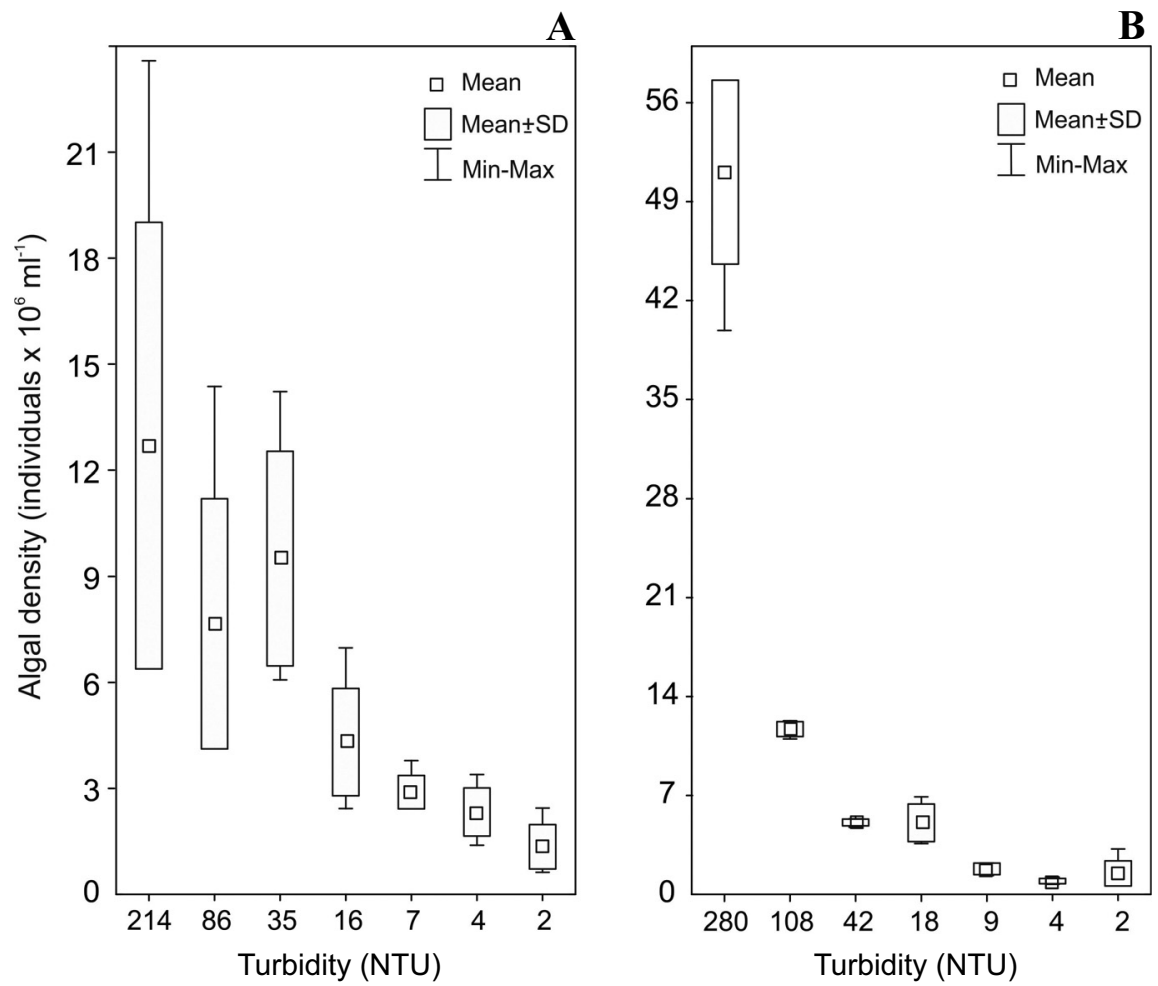

Figure 3. Box-plot diagrams for algal density at the turbidity levels obtained with both settling protocols. A: algal settling without homogenization (DS). B: settling with prior homogenization (HS). Diagramas de "box-plot" de la densidad de algas en los niveles de turbidez obtenidos con ambas técnicas de sedimentación. A: sedimentación sin homogeneización previa (DS). B: sedimentación con homogeneización previa $(H S)$. 


\section{Statistical analysis}

The relationship between algal density and turbidity was evaluated by regression analysis and the Pearson correlation method with fitting to a linear model. A factorial analysis of variance (ANOVA) was performed to test the effect of the turbidity and the zonal location within the settling chamber on algal density. The algal density was $\log$ transformed to meet the assumption of variance homogeneity. In cases where the $F$ test was significant, the multiple range test of Tukey was used to identify the groups.

\section{RESULTS}

Observations from microscopy and the analyses of the digital images confirmed that most parti- cles in the sedimentation chamber corresponded to the cultured algae (Fig. 2). The time required for the automated counting of the settled algae through the digital software (approximately one minute per field) was markedly less than that normally needed for counting of monospecific cultures (around five minutes per field).

The settled algae from the different aliquot volumes used for each turbidity level produced similar final algal concentration values among the different dilutions. Algal agglomerates or fields without algae were not observed (Fig. 2). In the automated sample counting for both protocols, a minimum of 17 and a maximum of 404 individuals/image were recorded. The mean values ranged between 102 and 215 individuals/image for the DS procedure and between 66 and 357 individuals/image for the settling with prior homogenization (HS) procedure. Two sets of data
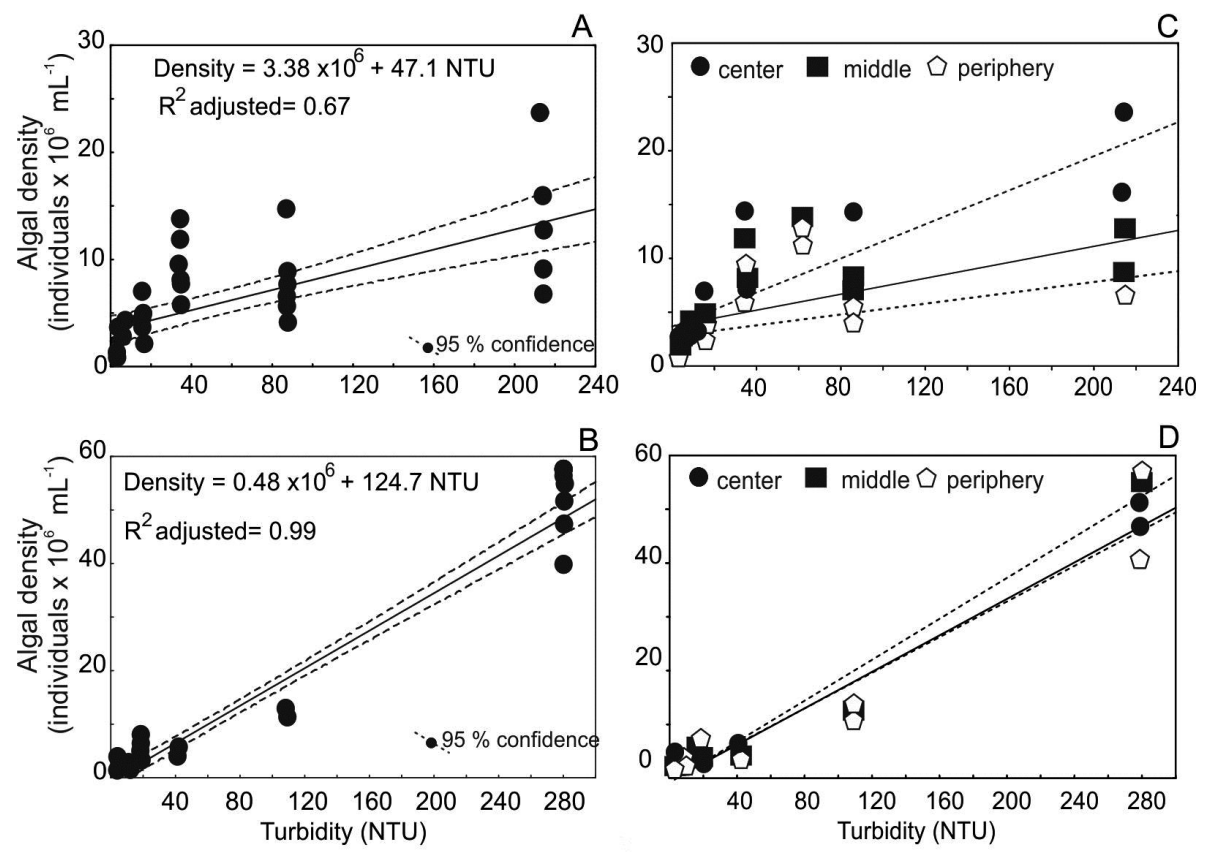

Figure 4. Result of regression analysis between turbidity (NTU) and algal density (individuals/ml). A: algal settling without prior homogenization (direct settling: DS). B: settling with prior homogenization (HS). C: turbidity versus algal density in each of the three designated sectors in the settling chamber (central, middle, peripheral) without homogenization. D: turbidity versus algal density in each of the three designated sectors established in the settling chamber (central, middle, peripheral) after previous homogenization. Resultado del análisis de regresión entre la turbidez (NTU) y la densidad algal (individuos/ml). A: Sedimentación sin homogeneización previa (sedimentación directa: DS). B. Sedimentación con homogeneización previa (HS).C: turbidez versus densidad algal para los tres sectores establecidos en la cámara de sedimentación (central, medio, periférico) sin homogeneización previa. D: turbidez versus densidad algal para los tres sectores establecidos en la cámara de sedimentación (central, medio, periférico) con homogeneización previa. 

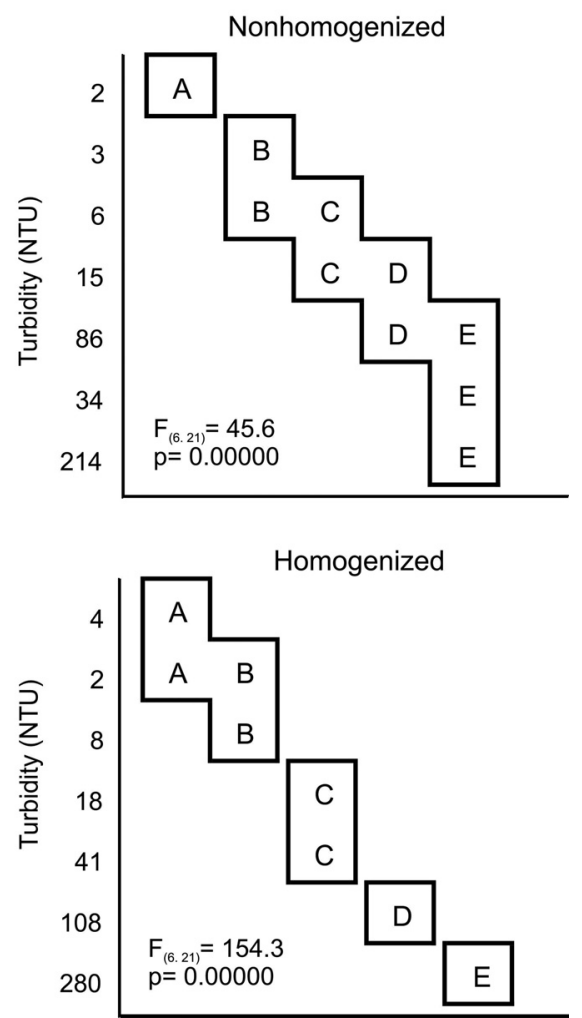

Figure 5. Results of Tukey's post-hoc test showing the homogeneous groups with turbidities for both methods. Resultados de la prueba "a posteriori" de Tukey mostrando los grupos homogéneos de turbidez para ambos métodos.

were identified on the basis of the counting errors obtained: 1) with turbidity levels greater than 30 NTUs, the error range with the DS procedure was higher than with the HS procedure and 2) with lower turbidity levels ( $<40$ NTUs), both protocols gave comparable errors (Table 2).

The standard deviation for the turbidity data was higher for the DS protocol (Fig. 3). Plots of turbidity as a function of algal density (Fig. 4A, 4B) proved to be significantly linear $(p<0.01)$ for both settling protocols, but the HS procedure resulted in less dispersion and therefore better graphical linearity $\left(R^{2}=0.99\right.$; Fig. $\left.4 \mathrm{~B}\right)$. Without the prior homogenization (Fig. 4C), a clear separation of the regression curves corresponding to the three sectors (central, middle, and peripheral) occurred. Contrastingly, when the algal suspension had been thoroughly mixed before being left to settle in the chamber, the plots of the three sectors overlapped (Fig. 4D).
The differences between the curves for the settling chamber sectors for both protocols, were non-significant (HS: $F_{12,21}=0.7, p=0.74$ and DS: $F_{12,21}=0.5, p=0.92$ ), although those differences for the overall turbidity versus density between the two methods were significant (HS: $F_{6,21}=45.6, p<0.001$ and DS: $F_{6,21}=154.3$, $p<0.001)$. ANOVA calculations for the sector effect within the settling chamber revealed significant differences for only the DS treatment (DS: $\left.F_{2,21}=12.6, p<0.001\right)$. Tukey's post-hoc analysis of these procedures showed significant differences between the peripheral zone, which showed lower algal density, and the other two chamber sectors. By contrast, the HS protocol resulted in no significant differences among chamber sectors, with those accordingly forming a single homogeneous group (Fig. 5).

Without the previous homogenization, overlap of the groups was observed throughout most of the turbidity range, except for the lowest level, but the separation between the homogeneous groups was greater for the HS procedure. In this case, the overlap was restricted to low turbidities, whereas the middle and high levels of turbidity became differentiated as separate groups by Tukey's post-hoc test (Fig. 6).

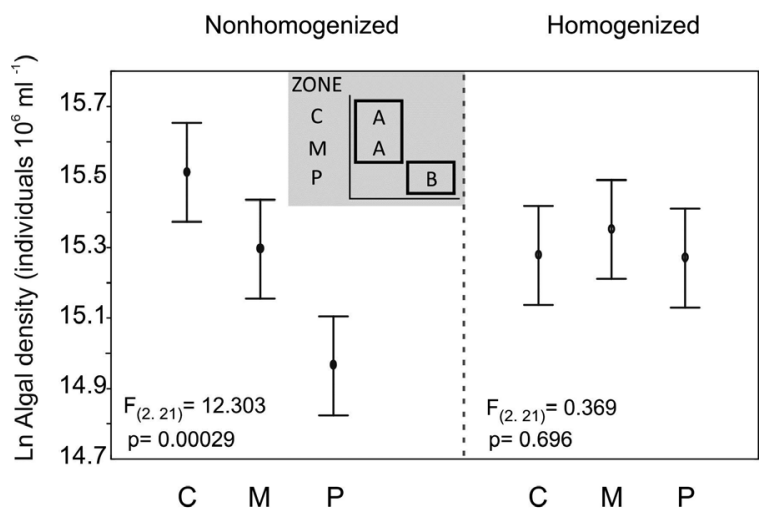

Figure 6. Results of ANOVA analyses of the chamber-sector effects (C: central, M: middle, P: peripheral) for both protocols. The grey box indicates Tukey's post-hoc test, showing the overlapping groups for the non-homogenized protocol. Resultados del análisis ANOVA del efecto de los sectores de la cámara (C: central, $M$ : medio, P: periférico) para ambos protocolos. El cuadro gris indica el test "a posteriori" de Tukey mostrando los grupos homogéneos en el método sin homogeneización previa. 


\section{DISCUSSION}

Automated electronic counters are suitable for algal density estimation as an immediate indicator of the state of the culture (Javanmardian \& Palsson, 1992), but the use of those instruments would be excessively expensive for laboratory cultures of algae and/or for aquaculture on a small scale. With the use of chlorophyll 'a' analysis (Travieso et al., 2006), the disadvantage is the absence of an immediate resolution, preventing the real-time monitoring and adjustment of the culture conditions. The same problem applies to the traditional algal counts (Lund et al., 1958; Willén, 1976), whose approach also involves a large investment of time, effort, and training (Embleton et al., 2003) and provokes sizeable errors when numerous cells of the same species are present within each single microscopic field (Rodas Gaitán et al., 2012). With respect to the latter method, however, when dilute samples are used from natural ecosystems (multiple species and algal densities $<16$ individuals/field), the ability to combine taxonomic determination and algal counts represents a distinct advantage in comparison with automatic counters (Embleton et al.,2003).

Our results, in agreement with those of Held (2011), indicate the usefulness of turbidimetry as a tool for monitoring the algal density of cultures in real time, which offers the advantage of obtaining an assessment of the culture' biomass without algal loss, thus allowing an adjustment of the conditions at the moment when the culture needs such an intervention. To apply turbidimetry in this way, however, an empirical relationship linking the results of algal density counts with the associated turbidity values must be developed. According to Held (2011), this relationship must be updated with calibration curves for each algal species, especially upon consideration of the variable relationship between algal size and culture conditions(Lee \& Palsson, 1994). Because the dependency of turbidity on algal numbers may vary in the same culture over time, the generation of calibration curves must be planned as a continuous process that includes the updating of the algal counts and their correlation with the culture turbidity.
Establishing the relationship between the algal density of a culture and its turbidity involves two principal difficulties. First, in algal cultures at high densities, the algal suspension must be diluted to obtain aliquots within a suitable density range for the proper identification of the algae during the processing of the image by the software. In this regard, agglomerations that could prevent algal identification by the automated counting software were not present, nor were fields with low densities or with the absence of individuals observed, in the quantitative analyses carried out to construct the calibration curves for this technique. These sources of error -i.e., agglomerations and low densities, as cited by Embleton et al. (2003) and Mazziotti \& Vadrucci (2007) - were avoided in the procedure described here through the judicious choice of aliquot dilutions for each algal density. Second, an excessive dispersion of the counting results would diminish the ability of the method to estimate accurately the algal density by turbidimetry. In our analysis, this problem became evident with the DS protocol and accordingly promoted a marked heterogeneity in the algal spatial distributions within the settling chamber with a consequent non-uniformity in the counting results for each sample. Using Neubauer chambers, Rodas Gaitán et al. (2012) found the same difficulty in algal cultures that became pronounced at high densities. The uniform sedimentation through the use of the HS protocol allowed a more reliable assessment of the relationship between turbidity and algal density, particularly when the turbidity exceeded 40 NTUs.

The implementation of cultures under low irradiance (West, 2005), and thus at reduced maintenance costs, allows the development of cultures that reach a maximum photosynthetic efficiency with chlorophyll ' $a$ ' concentrations exceeding $300 \mathrm{mg} / \mathrm{m}^{3}$ and low levels of algal mortality. This latter feature is significant for the purposes of image counting because the probability of scoring spores and/or dead cells is minimal. We believe that this technique is suitable for use in laboratory experiments. Furthermore, the method of digitalized algal counting significantly accelerated the process of validating the 
relationship between turbidity and algal density in contrast to what has been proposed by Embleton et al. (2003), who were able to perform manual counts over a short time period because of the lower densities of the cultures (16 individuals/field). In high density cultures, the observer error increases as a result of the large numbers of algae within the visual field and the small size of the algae, as stated by Lund et al. (1958). For this reason, the use of digital image counting vastly improves the counting accuracy.

We consider that algal density determination by turbidimetry may be applicable to those unicellular forms having a geometrical shape that can be recognized by the image processor. As part of these experiments, the method was also applied to Monoraphidium minutum and M. tortile and gave similar results. We also suggest that this type of turbidimetry with image processing could also be used for cultures of other coccal genera, such as Scenedesmus and Chlamydomonas, as well as for cryptomonads.

\section{ACKNOWLEDGEMENTS}

The authors wish to thank the two anonymous reviewers for their valuable comments on the manuscript. We are grateful to Dr. Donald F. Haggerty, a retired career investigator and native English speaker, for improving the English of the final version of the manuscript. Scientific Contribution Institute of Limnology Dr. R. A. Ringuelet No 957.

\section{REFERENCES}

ALTENBURGER, R, J., M. SCHMITT \& J. RIEDL. 2008. Bioassay with unicelular algae: deviations from exponential growth and its implications for toxicity test results. Journal of Environmental Quality, 37: 16-21.

AGUIRRE RAMÍREZ, N. J., J. A. PALACIO BAENA, I. C. CORREA OCHOA \& E. HERNÁNDEZ ATILIANO. 2007. Ensayos de bioestimulación algal con diferentes relaciones Nitrógeno: Fósforo, bajo condiciones de laboratorio. Revista Ingenierías Universidad de Medellín, 6: 11-21.
APHA. 1995. Standard methods for analysis of water and wastewater. 19 Ed. American Public Health Association, Washington D.C. USA.

BRENNAN, L. \& P. OWENDE. 2010. Biofuels from microalgae-A review of technologies for production, processing, and extractions of biofuels and co-products. Renewable \& Sustainable Energy Reviews, 14: 557-577.

CHINNASAMY, S., A. BHATNAGAR, R. HUNT \& K. C. DAS. 2010. Microalgae cultivation in a wastewater dominated by carpet mill effluents for biofuel applications. Bioresources Technology, 101: 3097-3105.

CHISTI, Y. 2007. Biodiesel from microalgae. Biotechnology Advances, 25: 294-306.

CONVERTI, A., A. A. CASAZZA, E. Y. ORTIZ, P. PEREGO \& M. DEL BORGHI. 2009. Chemical engineering and processing: process intensification. Chemical Engineering Processes, 48: 11461151.

DE PAUW, N., J. MORALES \& G. PERSOONE. 1984. Mass culture of microalgae in aquaculture systems: Progress and constraints. Hydrobiologia, 116-117: 121-134.

EMBLETON, K. E., C. E. GIBSON \& S. I. HEANEY. 2003. Automated counting of phytoplankton by pattern recognition: comparison with a manual counting method. Journal of Plankton Research, 25: 669-681.

FERREIRA, T. \& W. RASBAND. 2012. ImageJ User guide. http://rsbweb.nih.gov/ij/docs/guide/ user-guide.pdf)

FLORES-BURGOS, J., S. S. S. SARMA \& S. NANDINI. 2003. Population growth of zooplankton (rotifers and cladocerans) fed Chlorella vulgaris and Scenedesmus acutus in different proportions. Acta Hydrochimica et Hydrobiologica, 31: 240248.

HELCOM. 2014. Manual for Marine Monitoring in the COMBINE Programme of HELCOM. Annex 6: Guidelines concerning phytoplankton species composition, abundance and biomass (http://hel com.fi/action-areas/monitoring-and-assessment/ manuals-and-guidelines/combine-manual

HELD, P. 2011. Monitoring of Algal Growth Using their Intrinsic Properties. Use of a Multi-Mode Monochromator-based Microplate Reader for Biofuel Research. Application Note, Biofuel Research. BioTek Instruments, Inc., Vermont.

JAVANMARDIAN, M. \& B. Ø. PALSSON. 1992. Continuous photoautotrophic cultures of the euka- 
ryotic alga Chlorella vulgaris can exhibit stable oscillatory dynamics. Biotechnology Bioengineering, 39: 487-497.

LEE, C. \& B. Ø. PALSSON. 1994. High-density algal photobioreactors using light-emitting diodes. Biotechnology Bioengineering, 44: 1161-1167.

LORENZEN, C. J. 1967. Determination of chlorophyll and pheopigments spectrophotometric equations. Limnology and Oceanography, 12: 343-346.

LUND, J. W. G., C. KIPLING \& E. D. LE CREN. 1958. The inverted microscope method of estimating algal numbers and the statistical basis of estimations by counting. Hydrobiologia, 11: 143-170.

MAZZIOTTI, C. \& M. R. VADRUCCI. 2007. Methodological aspects of phytoplankton analysis in transitional waters. Transitional Waters Bulletin, 3: 9-12.

ORTIZ MORENO, M. L., C. E. CORTÉS CASTILLO, J. SÁNCHEZ VILLARRAGA, J. PADILLA \& A. M. OTERO PATERNITA. 2012. Evaluación del crecimiento de la microalga Chlorella sorokiniana en diferentes medios de cultivo en condiciones autotróficas y mixotróficas. Orinoquia, 16: 11-20.

PEÑA-AGUADO, F., S. NANDINI \& S. S. S. SARMA. 2005. Differences in population growth of rotifers and cladocerans raised on algal diets supplemented with yeast. Limnologica, 35: 298-303.

RODAS GAITÁN, H. A., H. RODRÍGUEZ FUENTES, G.FLORES MENDIOLA, J. A. VIDALES CONTRERAS, J. ARANDA RUIZ \& A. I. LUNA MALDONADO. 2012. Efecto de la densidad celular de inoculación en el crecimiento de Chlorella vulgaris CLV2 cultivada bajo condiciones mixotróficas. Revista Fitotécnia Mexicana, 35: 83-86.
SHAH, M. M. R., M. J. ALAM \& M. Y. MIA. 2003. Chlorella sp.: Isolation, pure culture and small scale culture in brackish water. Bangladesh Journal of Scientific and Industrial Research, 38: 164174.

SKIPNES, O., I. EIDE \& A. JENSEN. 1980. Cage Culture turbidostat: a device for rapid determination of algal growth rate. Applied and Environmental Microbiology, 40: 318-325.

TRAVIESO, L., F. BENÍTEZ, E. SÁNCHEZ, R. BORJA, A. MARTÍN \& M. F. COLMENAREJO. 2006. Batch mixed culture of Chlorella vulgaris using settled and diluted piggery waste. Ecological Engineering, 28: 158-165.

UTERMÖHL, H. 1958. Zur Vervollkommnung der quantitative Phytoplankton-Methodik. Mitteilungen Internationalen Vereinigung für theoretische und angewandte Limnologie, 9: 1-38.

WANG, C., C. FU \& Y. LIU. 2007. Effects of using light emitting diodes on the cultivation of Spirulina platensis. Biochemical Engineering Journal, 37: 21-25.

WEST, J. A. 2005. Long-Term Macroalgal Culture Maintenance 157-165 Algal Culturing Techniques Edited by Robert A. Andersen Elsevier.

WETZEL, R. G. \& G. E. LIKENS. 1991. Limnological analyses. Springer-Verlag, New York. USA.

WILLÉN, E. 1976. A simplified method of phytoplankton counting. British Phycological Journal, 11: 265-278.

XU, H., X. MIAO \& Q. WU. 2006. High quality biodiesel production from microalga Chlorella protothecoides by heterotrophic growth in fermenters. Journal of Biotechnology, 126: 499-507. 